\title{
Impact of Vitamins C and E Dietary Supplementation on Leukocyte Profile of Layer Hens Exposed to High Ambient Temperature and Humidity
}

\author{
Joachim Joseph Ajakaiye ${ }^{1}$, Alcides Perez-Bello ${ }^{1}$, Angel Mollineda-Trujillo ${ }^{1}$ \\ ${ }^{1}$ Department of Zootechnics and Veterinary Medicine, Universidad Central "Marta Abreu” de Las Villas, \\ Santa Clara, Villa Clara, Cuba \\ Received November 27, 2009 \\ Accepted March 8, 2010
}

\begin{abstract}
A 30-day experiment involving 720 White Leghorn layer hens was carried out to evaluate the effects of vitamins $\mathrm{C}$ and $\mathrm{E}$ on leukocyte and heterophil/lymphocytes ratios of the layer hens during the natural summer conditions. The birds were divided into 4 groups, one control with basal diet and three experimental with diet supplemented with vitamin $\mathrm{C}$, vitamin $\mathrm{E}$, or combination of both vitamins. Each group was divided into 4 subgroups. Exposure of layer hens to $31 \pm 3{ }^{\circ} \mathrm{C}$ and $33 \pm 0{ }^{\circ} \mathrm{C}$ ambient temperature and $84.6 \%$ and $81.5 \%$ relative humidity during the experiment caused an increase in the value of temperature humidity index of 15.5 above the threshold value of 70 established for this species. Total white blood cells, lymphocytes, and eosinophil levels were significantly $(p<0.001)$ higher in all treated groups compared to control. Similarly, heterophil/lymphocyte ratios of $0.51,0.52$, and 0.50 for groups with diet supplemented with vitamin $\mathrm{C}$, vitamin $\mathrm{E}$ and vitamins $\mathrm{C}+\mathrm{E}$, respectively, were significantly $(p<0.001)$ lower compared to 0.59 recorded in the control group. However, heterophil, basophil and monocyte values were significantly $(p<0.001)$ higher in the control group compared to all treated groups. The results of the present study showed that dietary supplementation of vitamins $\mathrm{C}$ and $\mathrm{E}$, or their combination, reduces the harmful effect of high ambient temperature and humidity on the leukocyte indicators of exposed layer hens, thereby alleviating the stress imposed on their thermoregulatory mechanism and physiological status.
\end{abstract}

Heat stress, antioxidant vitamins, white blood cells, laying birds

All over the world, farmers have to solve a problem of heat stress in poultry during the summer period. Global warming as a result of increased industrialization and environmental degradation has led to continuous increase in ambient temperature, thereby making heat stress a major problem of livestock farming, particularly in the poultry sector (Daghir 2009). This is because poultry are particularly sensitive to high ambient temperature (AT), more than to cold. Heat stress interferes with the birds' comfort and suppresses production efficiency. In birds, high ambient temperature leads to increased endogenous heat production, since convective transfer of heat is the major thermoregulatory mechanism of birds and depends on air movement by natural or fan-powered ventilation (Shane 2005). As a response, birds have to make major thermo-regulatory adaptations to prevent death from heat exhaustion. As a result, the genetic potential of layer hens is often compromised (Holik 2009). The responses of poultry to high ambient temperatures have been studied several times, but the effect of relative humidity (RH) on intensifying or modifying these responses has received little attention. Relative humidity is rarely included as an experimental variable or measured for information purposes. Such information is important because in poultry-producing regions high temperature can often be accompanied by a range of $\mathrm{RH}$, which can markedly affect the degree of heat stress in birds (Balnave 2004). The combination of high ambient temperature and relative humidity induces high corticosteroid concentrations in blood (Siegel 1980; Beuving et al. 1989). In addition, the relationship between adrenocorticotropic hormone (ACTH) and leukocyte response has been widely examined. It has been reported that the proportions of leukocytes change significantly when ACTH is administered either by injection (Gray

Address for correspondence:

Dr. Joachim Joseph Ajakaiye

Department of Zootechnics and Veterinary Medicine

Universidad Central "Martha Abreu" de Las Villas, Km 51/2 Carretera a Camajuani

P. O. 54830, Santa Clara, Villa Clara, Cuba

Phone: +5352416288

E-mail: joachim@uclvedu.cu

http://www.vfu.cz/acta-vet/actavet.htm 
et al. 1989) or in feed (Gross et al. 1980). In hens, changes of leukocytes in response to stress have been found to be less variable and thus a more reliable indicator than plasma corticosterone values (Gross and Siegel 1983; McFarlane and Curtis 1989). Heat stress has been found to decrease lymphocyte numbers and increase plasma corticosterone concentrations in cockerels (Ben Nathan et al. 1976). Altan et al. (2000) reported that after a $2 \mathrm{~h}$ heat stress, broiler chickens exhibited significantly reduced lymphocyte and raised heterophil ratios. As a consequence, the heterophil/lymphocyte ratio $(\mathrm{H} / \mathrm{L})$ increased from 0.25 to 0.43 . The authors also observed that acute heat-stressed broilers responded with a significant increase in basophil. Thaxton et al. (1968) were the first to demonstrate that high environmental temperature $\left(44.4\right.$ to $47.8^{\circ} \mathrm{C}$ ) affects the development of specific immune responses in young chickens. These effects include the suppression of circulating white blood cells (Heller et al. 1979) and an increase in H/L ratio (Mogenet and Youbicier-Simo 1998), which is an indicator of stress (Gross and Siegel 1983).

There are various strategies to minimize heat stress in layer hens either by changing their environmental condition or by modification of their diets. Nutritional strategy during heat period is based on diet balancing in order to cover the needs of stressed birds for amino acids (protein), energy and electrolytes (Balnave 2004; Daghir 2009). For this purpose, vitamin $\mathrm{C}$ and vitamin $\mathrm{E}$ are used in the poultry diet because of their anti-oxidant effect in the neutralization of the free radicals generated during heat stress (Ramnath et al. 2008). Poultry can synthesize vitamin $\mathrm{C}$ but its quantity is insufficient for reduction of free radicals (Maurice et al. 2002). Kevin (1982) showed that dietary supplementation of vitamin E increased the fertility of poultry, supported normal testicular functions of cockerels, layability as well as the hatchability of breeder eggs. Because radical reactions are exergonic, they contribute to the failure of thermoregulatory process in hyperthermia observed during heat stress (Mujahid et al. 2005).

The aim of this study therefore was to investigate the possible beneficial effects of dietary vitamin $\mathrm{C}$ and vitamin $\mathrm{E}$ supplementation on the leukocyte profile of layer hens subjected to chronic heat stress.

\section{Materials and Methods}

Experimental site

The study was conducted at the poultry production unit of "Las casas II", located at $51 / 2 \mathrm{~km}$ along Santa Clara and Camjauni highway in the province of Villa Clara in Cuba. It is located between $22^{\circ} 53^{\prime} \mathrm{N}$ and $82^{\circ} 02^{\prime} \mathrm{W}$, with an altitude between $90-100 \mathrm{~m}$ above sea level. Total precipitation during the study period was $327.2 \mathrm{~mm}$, while average air velocity was $3.15 \mathrm{~m} / \mathrm{s}$.

Meteorological data

The ambient tempareture and relative humidity were measured with standard ambient thermometer, and wet and dry-bulb hygrometer, respectively. Both instruments were obtained from Cocet, China. All measurements were recorded daily inside and outside the pen at experimental sites at 06:00, 09:00, 12:00, 15:00 and 18:00 h throughout the study period. THI values were calculated from observed measurement as described below by (Bouraoui et al. 2002).

$\mathrm{THI}=1.8 \times \mathrm{DBT}-(1-\mathrm{RH}) \times(\mathrm{DBT}-14.3)+32$

Where: THI = Temperature-humidity index;

DBT $=$ Dry-bulb temperature $\left({ }^{\circ} \mathrm{C}\right)$;

$\mathrm{RH}=$ Air relative humidity as fraction of a unit.

Experimental birds

The experiment was in accordance with animal welfare and was conducted under protocols approved by the Department of Zootechnics and Veterinary Medicine of the Faculty of Agricultural Sciences, Central University "Marta Abreu" of Las Villas, Cuba.

A total of 720, 39-week-old commercial White Leghorn $\left(\mathrm{L}_{33)}\right.$ layer hens of average live weight of $1.8 \pm 0.4 \mathrm{~kg}$, were used for the experiment. The birds were randomly divided within the production pen into four groups of 180. Each group was further divided into four subgroups of 45 birds with three birds per cage of $4.1 \times$ $4.1 \times 4.3 \mathrm{~m}$ dimension at a stocking rate of $500 \mathrm{~cm}^{2} / \mathrm{bird}$. There was one control group fed the basal diet and three experimental groups. The first experimental group was fed the basal diet supplemented with $150 \mathrm{mg}$ of L-ascorbic $\mathrm{acid} / \mathrm{kg}$ of diet (vitamin C group). The second experimental group was fed the basal diet supplemented with $150 \mathrm{mg}$ of $\alpha$-DL-tocopherol acetate/kg of diet (vitamin E group). The third experimental group was supplemented 
with $150 \mathrm{mg}$ of L-ascorbic acid/kg of diet plus $150 \mathrm{mg}$ of $\alpha$-DL-tocopherol acetate/ $\mathrm{kg}$ of diet (vitamin C $+\mathrm{E}$ group). Vitamins $\mathrm{C}$ and $\mathrm{E}$ used in the experiment were from a commercial company (VMD, Arendonk, Belgium). Prior to the experiment the birds were dewormed and vaccinated according to UECAN (2002) specifications. In addition, specific faecal flotation method with modified Sheather's solution (David and Lindquist 1982) was used to confirm the absence of helminths in the birds before the experiment. The birds were fed the basal diet of $110 \mathrm{~g} / \mathrm{bird} /$ day, while tap water was given ad libitum. Composition and bromatological analysis of the basal diet calculated according to AOAC (1990) are in Table 1 . The basal diet was calculated to slightly exceed the nutrient requirements recommended by the National Research Council (NRC 1994).

Table 1. Composition and bromatological analysis of the basal diet during the study period

\begin{tabular}{|c|l|c|}
\hline $\mathrm{S} / \mathrm{N}$ & Nutrients/constituents & Quantity $(\mathrm{kg})$ \\
\hline 1 & Maize & 607 \\
\hline 2 & Soya cake & 268 \\
\hline 3 & Vegetable oil & 11 \\
\hline 4 & Calcium carbonate & 91.7 \\
\hline 5 & Monocalcium phosphate & 11.2 \\
\hline 6 & Monocalcium & 0.7 \\
\hline 7 & Choline chloride & 3.0 \\
\hline 8 & Sodium chloride & 2.5 \\
\hline 9 & Pre-mix* & 1.5 \\
\hline 10 & Minerals & 1.5 \\
\hline 11 & DL-methionine & 1.9 \\
\hline \multicolumn{3}{|c|}{ Calculated bromatological analysis } \\
\hline \multicolumn{2}{|c|}{11.5} \\
\hline \multicolumn{2}{|c|}{16.5} \\
\hline & PE, MJ (kg) & \\
\hline & Ca (\%) & 0.52 \\
\hline & Ash (\%) & 12.60 \\
\hline
\end{tabular}

Source: UEB feed factory, Ministry of Agriculture, Villa Clara (2009) *To provide the following per $(\mathrm{kg})$ of diet: vitamin $\mathrm{A}, 10000 \mathrm{IU}$; vitamin D3, $2000 \mathrm{IU}$; vitamin E, $5 \mathrm{IU}$; vitamin $\mathrm{K}_{3}, 2 \mathrm{mg}$; riboflavin, $4.20 \mathrm{mg}$; vitamin $\mathrm{B}_{12}, 0.01 \mathrm{mg}$; panthothenic acid, $5 \mathrm{mg}$; nicotinic acid, $20 \mathrm{mg}$; folic acid, $0.5 \mathrm{mg}$; choline, $3 \mathrm{mg}$; $\mathrm{Mg}, 56 \mathrm{mg}$; Fe, $20 \mathrm{mg}$; $\mathrm{Cu}, 10 \mathrm{mg} ; \mathrm{Zn}, 50 \mathrm{mg} ; \mathrm{Co}, 125 \mathrm{mg}$ and Iodine, $0.08 \mathrm{mg}$. (SAS User's Guide 1985). The significance of differences between mean values computed for particular levels of experimental factors was determined by Duncan (1955) post-hoc test and means that differed at $p<0.05$ were considered significant.

\section{Results}

The meteorological data obtained during the experimental period are presented in Table 2. Throughout the study period, the ambient temperature outside and inside the pen showed a similar pattern of increase from 9:00 h to 15:00 h, and subsequently decreased from 15:00 h to 18:00 h. Ambient temperature measured outside was higher $(p<0.05)$ than inside. However, the mean relative humidity inside the pen was significantly $(p<0.05)$ higher than outside. The temperature humidity index (THI) results during the study period are shown in Table 3 . The minimum THI value of 77.8 was recorded at $18.00 \mathrm{~h}$, while the maximum value of 93.5 was recorded at $12.00 \mathrm{~h}$. The highest range value of 14.6 during the experimental period was recorded at $15.00 \mathrm{~h}$, corresponding to the hottest period of the day. But a slightly higher range value of 15.7 was obtained when the overall maximum and minimum temperature were compared. The lowest THI value of 83.1 was recorded at 9:00 h in the coolest period of the day, while the highest value of 89.1 at 15:00 h corresponded to the hottest period of the day. The overall mean THI value was 85.5 during the same period. 
The results of the leukocyte profile and heterophil/lymphocyte ratio are shown in Table 4. Total white blood cells, lymphocytes and eosinophils were significantly $(p<$ 0.001) higher in all treated groups compared to control. In control group, the decrease in contents of these indicators was observed from the second week, whereas there were no significant $(p>0.001)$ differences between the first and the second week for these indicators in all treated groups. This could probably suggest the commencement of the antioxidants effects of the vitamins. However, the converse was observed for heterophils, basophils and monocytes. For these indicators, the lowest values were recorded in group with diet supplemented with both vitamins $\mathrm{C}$ and E. Similarly, heterophil/lymphocyte ratio, a stress indicator, was observed to be significantly $(p<0.001)$ higher in control compared to supplemented groups; although there were no significant $(p>0.05)$ differences in the $\mathrm{H} / \mathrm{L}$ ratio between supplemented groups. The lowest $\mathrm{H} / \mathrm{L}$ ratio was recorded in the group with diet supplemented with both vitamins $\mathrm{C}$ and $\mathrm{E}$.

Table 2. Meteorological data of ambient temperature and relative humidity during the study period

\begin{tabular}{|c|c|c|c|c|c|c|c|c|}
\hline \multirow{2}{*}{ Hour } & \multicolumn{4}{|c|}{ Ambient temperature $\left({ }^{\circ} \mathrm{C}\right)$} & \multicolumn{4}{c|}{ Relative humidity (\%) } \\
\cline { 2 - 9 } & Out & In & SD & $P$ & Out & In & SD & $P$ \\
\hline $9: 00$ & $31.8^{\mathrm{a}}$ & $29.4^{\mathrm{b}}$ & \pm 0.527 & 0.000000 & $85.6^{\mathrm{b}}$ & $88.6^{\mathrm{a}}$ & \pm 1.729 & 0.021388 \\
\hline $12: 00$ & $35.6^{\mathrm{a}}$ & $33.3^{\mathrm{b}}$ & \pm 0.421 & 0.000000 & $75.4^{\mathrm{b}}$ & $81.4^{\mathrm{a}}$ & \pm 1.908 & 0.000071 \\
\hline $15: 00$ & $35.8^{\mathrm{a}}$ & $34.0^{\mathrm{b}}$ & \pm 0.848 & 0.003532 & $78.6^{\mathrm{a}}$ & $79.6^{\mathrm{a}}$ & \pm 2.529 & 0.436896 \\
\hline $18: 00$ & $29.0^{\mathrm{a}}$ & $28.5^{\mathrm{a}}$ & \pm 0.619 & 0.242058 & $86.3^{\mathrm{a}}$ & $88.9^{\mathrm{a}}$ & \pm 1.972 & 0.067726 \\
\hline Mean & $33.0^{\mathrm{a}}$ & $31.3^{\mathrm{b}}$ & \pm 0.583 & 0.000024 & $81.5^{\mathrm{b}}$ & $84.6^{\mathrm{a}}$ & \pm 1.312 & 0.000736 \\
\hline
\end{tabular}

For each indicator, mean values with different superscript alphabets along the same row are significantly $(p<0.05)$ different

Table 3. Temperature and humidity index of $\mathrm{L}_{33}$ layer hens during the experimental period

\begin{tabular}{|r|c|c|c|c|c|}
\hline Hours & Average & S & Minimum & Maximum & Range \\
\hline $9: 00$ & 83.1 & 2.510 & 79.6 & 91.0 & 11.4 \\
\hline $12: 00$ & 88.4 & 1.767 & 85.6 & 93.5 & 7.9 \\
\hline $15: 00$ & 89.1 & 2.915 & 78.5 & 93.1 & 14.6 \\
\hline $18: 00$ & 81.6 & 2.367 & 77.8 & 87.0 & 9.2 \\
\hline Mean & 85.5 & 4.056 & 77.8 & 93.5 & 15.7 \\
\hline
\end{tabular}

\section{Discussion}

In this study, the ambient temperature both inside and outside the pen during the experiment were higher than the recommended normothermia zone of $22-28{ }^{\circ} \mathrm{C}$ (Donkoh 1989) or $18-24^{\circ} \mathrm{C}$ (Holik 2009) established for poultry in the tropical regions. The combination of $31.3{ }^{\circ} \mathrm{C}$ and $33.0^{\circ} \mathrm{C}$ recorded for AT with $84.6 \%$ and $81.5 \%$ recorded for relative humidity were calculated to give a temperature humidity index (THI) of 85.5, a value above the THI threshold of 70, established for poultry (Bouraoui et al. 2002; Karaman et al. 2007). This is a clear indication that the layer hens in this experiment were exposed to heat stress. Diet supplemented with vitamin $\mathrm{C}$ and $\mathrm{E}$ improved the stability of leukocytes of layer hens exposed to high ambient temperature and humidity. Chronic heat stress caused changes in the proportions of leukocytes. Total leukocyte count (TLC), lymphocyte and eosinophils were significantly reduced, while heterophil/lymphocyte ratio increased from 0.49 to 0.68. This finding is in agreement with Altan et al. (2000), Minka and Ayo (2008), who observed an increase in $\mathrm{H} / \mathrm{L}$ ratio after heat and transportation stress in broiler and layer hens, respectively. Likewise, Nworgu et al. (2007) and Minka and Ayo (2008) reported stability in the values of TLC and $\mathrm{H} / \mathrm{L}$ ratio after treatment with vitamin $\mathrm{C}$ and antioxidant 
Table 4. Leukocyte profile and H/L ratios of layer hens supplemented with vitamins $\mathrm{C}$ and $\mathrm{E}(\mathrm{n}=20)$

\begin{tabular}{|c|c|c|c|c|c|}
\hline \multirow{2}{*}{$\begin{array}{l}\text { Indicators } \\
\text { in weeks }\end{array}$} & \multicolumn{4}{|c|}{ Treatment } & \multirow{2}{*}{$\mathrm{SD} \pm$} \\
\hline & Vit. C & Vit. E & Vit. $\mathrm{C}+\mathrm{E}$ & Control & \\
\hline \multicolumn{6}{|c|}{ Total leukocyte counts $\left(\times 10^{9} / 1\right)$} \\
\hline 1 & $3.50^{\mathrm{a}}$ & $3.56^{\mathrm{a}}$ & $3.49^{\mathrm{a}}$ & $3.54^{\mathrm{a}}$ & \pm 0.015 \\
\hline 2 & $3.51^{\mathrm{a}}$ & $3.49^{\mathrm{a}}$ & $3.52^{\mathrm{a}}$ & $3.01^{\mathrm{b}}$ & $\pm 0.015^{* * * *}$ \\
\hline 4 & $3.52^{\mathrm{a}}$ & $3.50^{\mathrm{a}}$ & $3.53^{\mathrm{a}}$ & $2.48^{b}$ & $\pm 0.016^{* * *}$ \\
\hline mean & $3.51^{\mathrm{a}}$ & $3.52^{\mathrm{a}}$ & $3.51^{\mathrm{a}}$ & $3.01^{\mathrm{b}}$ & $\pm 2.944^{* * *}$ \\
\hline \multicolumn{6}{|c|}{ Lymphocytes (\%) } \\
\hline 1 & $57.81^{\mathrm{a}}$ & $58.24^{\mathrm{a}}$ & $58.73^{\mathrm{a}}$ & $58.51^{\mathrm{a}}$ & \pm 0.143 \\
\hline 2 & $57.40^{\mathrm{a}}$ & $57.60^{\mathrm{a}}$ & $58.01^{\mathrm{a}}$ & $54.02^{\mathrm{b}}$ & $\pm 0.186^{* * *}$ \\
\hline 4 & $56.90^{\mathrm{b}}$ & $55.70^{\mathrm{c}}$ & $57.80^{\mathrm{a}}$ & $49.20^{\mathrm{d}}$ & $\pm 0.151^{* * * *}$ \\
\hline mean & $57.37^{\mathrm{ab}}$ & $57.15^{\mathrm{b}}$ & $58.17^{\mathrm{a}}$ & $53.90^{\mathrm{c}}$ & $\pm 0.317^{* * * *}$ \\
\hline \multicolumn{6}{|c|}{ Heterophils (\%) } \\
\hline 1 & $29.00^{\mathrm{a}}$ & $28.24^{\mathrm{a}}$ & $28.61^{\mathrm{a}}$ & $28.93^{\mathrm{a}}$ & \pm 0.184 \\
\hline 2 & $29.21^{\mathrm{b}}$ & $29.00^{b}$ & $28.82^{\mathrm{b}}$ & $31.41^{\mathrm{a}}$ & $\pm 0.156^{* * * *}$ \\
\hline 4 & $29.20^{\mathrm{c}}$ & $29.90^{\mathrm{b}}$ & $29.40^{\mathrm{bc}}$ & $33.60^{\mathrm{a}}$ & $\pm 0.116^{* * * *}$ \\
\hline mean & $29.13^{\mathrm{b}}$ & $29.03^{\mathrm{b}}$ & $28.93^{b}$ & $31.28^{\mathrm{a}}$ & $\pm 0.222^{* * * *}$ \\
\hline \multicolumn{6}{|c|}{ Eosinophils (\%) } \\
\hline 1 & $5.92^{\mathrm{a}}$ & $6.21^{\mathrm{a}}$ & $6.53^{\mathrm{a}}$ & $6.00^{\mathrm{a}}$ & \pm 0.098 \\
\hline 2 & $6.00^{\mathrm{a}}$ & $5.82^{\mathrm{a}}$ & $5.83^{\mathrm{a}}$ & $3.64^{\mathrm{b}}$ & $\pm 0.084^{* * *}$ \\
\hline 4 & $7.60^{\mathrm{a}}$ & $6.40^{\mathrm{b}}$ & $6.20^{\mathrm{b}}$ & $5.00^{c}$ & $\pm 0.129^{* * * *}$ \\
\hline mean & $6.50^{\mathrm{b}}$ & $6.13^{\mathrm{a}}$ & $6.17^{\mathrm{a}}$ & $4.87^{\mathrm{a}}$ & $\pm 0.148^{* * * *}$ \\
\hline \multicolumn{6}{|c|}{ Basophils (\%) } \\
\hline 1 & $3.81^{\mathrm{a}}$ & $3.43^{\mathrm{a}}$ & $3.44^{\mathrm{a}}$ & $3.63^{\mathrm{a}}$ & \pm 0.101 \\
\hline 2 & $3.21^{\mathrm{a}}$ & $3.23^{\mathrm{a}}$ & $3.04^{\mathrm{a}}$ & $3.80^{\mathrm{a}}$ & \pm 0.098 \\
\hline 4 & $3.20^{\mathrm{b}}$ & $3.20^{\mathrm{b}}$ & $3.00^{\mathrm{b}}$ & $3.80^{\mathrm{a}}$ & $\pm 0.083^{*}$ \\
\hline mean & $3.38^{\mathrm{b}}$ & $3.25^{\mathrm{b}}$ & $3.13^{\mathrm{b}}$ & $3.72^{\mathrm{a}}$ & $\pm 0.109^{* * * *}$ \\
\hline \multicolumn{6}{|c|}{ Monocytes (\%) } \\
\hline 1 & $3.62^{\mathrm{ab}}$ & $4.14^{\mathrm{a}}$ & $2.83^{\mathrm{b}}$ & $3.14^{\mathrm{b}}$ & $\pm 0.131^{* *}$ \\
\hline 2 & $4.22^{b}$ & $4.41^{b}$ & $4.40^{\mathrm{b}}$ & $7.31^{\mathrm{a}}$ & $\pm 0.140^{* * * *}$ \\
\hline 4 & $3.10^{\mathrm{c}}$ & $4.90^{\mathrm{b}}$ & $3.60^{\mathrm{c}}$ & $8.40^{\mathrm{a}}$ & $\pm 0.129^{* * * *}$ \\
\hline mean & $3.62^{\mathrm{c}}$ & $4.43^{b}$ & $3.60^{\mathrm{c}}$ & $6.23^{\mathrm{a}}$ & $\pm 0.220^{* * * *}$ \\
\hline \multicolumn{6}{|l|}{$\mathrm{H} / \mathrm{L}$} \\
\hline 1 & $0.50^{\mathrm{a}}$ & $0.48^{\mathrm{a}}$ & $0.49^{\mathrm{a}}$ & $0.49^{\mathrm{a}}$ & \pm 0.004 \\
\hline 2 & $0.51^{\mathrm{b}}$ & $0.50^{\mathrm{b}}$ & $0.50^{\mathrm{b}}$ & $0.58^{\mathrm{a}}$ & $\pm 0.004^{* * * *}$ \\
\hline 4 & $0.51^{\mathrm{c}}$ & $0.57^{b}$ & $0.51^{\mathrm{c}}$ & $0.68^{\mathrm{a}}$ & $\pm 0.129^{* * *}$ \\
\hline mean & $0.51^{\mathrm{b}}$ & $0.52^{\mathrm{b}}$ & $0.50^{\mathrm{b}}$ & $0.59^{\mathrm{a}}$ & $\pm 0.009^{* * * *}$ \\
\hline
\end{tabular}

$\mathrm{H} / \mathrm{L}=$ Relation heterophil/lymphocyte; $\mathrm{TLC}=$ Total leukocyte counts, $\mathrm{SD} \pm=$ Standard deviation. Means values with different superscripts alphabets along the same row are significantly different. Level of significance: $*(p<0.05), * *(p<0.01), * * *(p<0.001)$. Results are expressed as means \pm standard deviations.

fluted pumpkins. In our experiment, a significant increase in basophils and monocytes counts in control group was observed. This finding is in agreement with the findings of Mitchell et al. (1992) and Maxwell et al. (1992), who observed an increase in basophil counts after heat stress. Maxwell et al. (1992) and Maxwell (1993) suggested that an increase in the $\mathrm{H} / \mathrm{L}$ ratio may be a response to mild or moderate stress but a basophilia may result from extreme stress, such as life-threatening situations. Although the H/L ratio of 0.43 shows usual stress according to Gross and Siegel (1983), basophilia observed in this study showed that exposure of the layer hens to $31.3{ }^{\circ} \mathrm{C}$ for 30 days produced 
significant heat stress in these birds. In the review of Maxwell and Robertson (1998), it was reported that during stress, particularly acute one, eosinophils disappear from blood circulation while basophils counts increase in blood circulation. Overall antioxidant potential has been reported to be more efficient and crucial than single antioxidant nutrients (Gey 1998; German and Traber 2001).

The results of this experiment showed that the combination of $150 \mathrm{mg}$ of vitamin $\mathrm{C}$ and $150 \mathrm{mg}$ of vitamin $\mathrm{E}$ provided the greatest protection on leukocytes profile of $\mathrm{L}_{33}$ layer hens exposed to harmful effect of high ambient temperature and relative humidity.

\section{Acknowledgement}

We thank the Director General, National Union of Combined Avian Company (UECAN, Cuba) for granting us the permission to carry out this experiment in one of their production pen.

\section{References}

Altan O, Altan A, Cabuk M, Bayraktar H 2000: Effects of heat stress on some blood parameters in broilers. Turk J Vet Anim Sci 24: 145-148

AOAC 1990: Association of Official Analytical Chemists. Official methods of analysis. $15^{\text {th }}$ Ed. Washington D.C. pp. 1298-1930

Balnave D 2004: Challenges of accurately defining the nutrient requirements of heat-stressed poultry. In: World's Poultry Science Association Invited Lecture. Poult Sci 83: 5-14

Ben-Nathan D, Heller ED, Perek M 1976: The effect of short heat stress upon leukocyte count, plasma corticosterone level, plasma and leukocyte ascorbic acid content. Br Poult Sci 17: 481-485

Beuving G, Jones RB, Blokhuis HJ 1989: Adrenocortical and heterophil/lymphocyte responses to challenge in hens showing short or long tonic immobility reactions. Br Poult Sci 30: 175-184

Bouraoui R, Lahmar M, Majdoub A, Djemali M, Belyea R, 2002: The relationship of temperature-humidity index with milk production of dairy cows in a Mediterranean climate. Anim Res 51: 479-491

Campbell TW 1995: Avian hematology. In: Campbell TW (ED.): Avian hematology and cytology. Iowa State University Press, Ames, Iowa, pp. 3-19

Daghir NJ 2009: Nutritional strategies to reduce heat stress in broilers and broiler breeders. Lohmann Information 44: 6-15

David ED, Lindquist WD 1982: Determination of the specific gravity of certain helminthes eggs using sucrose density gradient centrifugation. J Parasitol 68: 916-919

Donkoh A 1989: Ambient temperature: A factor affecting performance and physiological response of broiler chickens. Intl J Biomet 33: 259-265

Duncan DB 1955: Multiple range and multiple F tests. Biometrics 11: 1-42

German JB, Traber MG 2001: Nutrients and oxidation: Actions, transport, and metabolism of dietary antioxidants. In: Handbook of vitamins. $3^{\text {rd }}$ Ed Rucker RB, Suttie JW, McCormick DB, Machlin LJ Marcel Dekker Inc New York, pp. 569-588

Gey KF 1998: Vitamins C plus E and interacting co-nutrients required for optimal health. BioFactors 7: 113-174

Gray HG, Paradis TJ, Chang PW 1989: Physiological effects of adrenocorticotropic hormone and hydrocortisone in laying hens. Poult Sci 68: 1710-1713

Gross WB, Siegel PB, Dubose RT 1980: Some effects of feeding corticosterone to chickens. Poult Sci 59: 516-522

Gross WB, Siegel HS 1983: Evaluation of the heterophil/lymphocyte ratio as a measure of stress in chickens. Avian Dis 27: 972-979

Heller ED, Nathan DB, Perek M 1979: Short heat stress as an immunostimulant in chicks. Avian Pathol 8: 195-203

Holik V 2009: Management of laying hens to minimize heat stress. Lohmann Information 44: 16-29

Karaman S, Tarhan S, Ergunes G 2007: Analysis of indoor climatic data to assess the heat stress of laying hens. IJNES 1: 65-68

Kevin C 1982: Vitamin E in poultry production. $1^{\text {st }}$ Iberian Symposium on aviculture. In: ROCHE Information Service, Animal Nutrition Department, Lisbon, Portugal. pp. 1-6.

Maurice DV, Lightsey SF, Abudabos A, Toler JE 2002: Factors affecting ascorbic acid biosynthesis in chickens: III. Effect of dietary fluoride on L-gulonolactone oxidase activity and tissue ascorbic acid (AsA) concentration. J Anim Physiol Anim Nutr 86: 383-388

Maxwell MH, Robertson GM 1998: The avian heterophil leukocyte: a review. World's Poult Sci J 54: 155-178

Maxwell MH, Robertson GM, Mitchell MA, Carlisle AJ 1992: The fine structure of broiler chicken blood cells, with particular reference to basophils, after severe heat stress. Comparative Hematol Intl 2: 190-200

Maxwell MH 1993: Avian blood leukocyte responses to stress. World's Poult Sci J 49: 34-43

McFarlane JM, Curtis SE 1989: Multiple concurrent stressors in chicks. 3. Effects on plasma corticosterone and the heterophil: lymphocyte ratio. Poult Sci 68: 522-527 
Minka NS, Ayo JO 2008: Haematology and behavior of pullets transported by road and administered ascorbic acid during the hot-dry season. Res Vet Sci 85: 389-393

Mitchell MA, Kettlewell PJ, Maxwell MH 1992: Indicators of physiological stress in broiler chickens during road transportation. Anim Welfare 1: 91-103

Mogenet LY, Youbicier-Simon BJ 1998: Determination of reliable biochemical parameters of heat stress, and application to the evaluation of medications: example of erythromycin. In: Proceedings of $10^{\text {th }}$ European Poultry Conference, Jerusalem, Israel, pp. 538-541

Mujahid A, Yoshiki Y, Akiba Y, Toyomizu M 2005: Superoxide radical production in chicken skeletal muscle induced by acute heat stress. Poult Sci 84: 307-314

NRC 1994: Nutrient requirements of poultry. 9th rev. Ed. National Academy of Science Washington D.C, pp. 19-26

Nworgu FC, Ogungbenro SA, Solesi KS 2007: Performance and some blood chemistry indices of broiler chicken served fluted pumpkin (Telfaria occidentalis) leaves extract supplement. American-Eurasian J Agric Environ Sci 2: 90-98

Ramnath V, Rekha PS, Sujatha KS 2008: Amelioration of heat stress induced disturbances of antioxidant defense system in chicken by Brahma Rasayana. Evidence- Based Compl Alt Med 5: 77-84

SAS USER'S GUIDE 1985: Statistics In: Joyner SP. Ed. The GLM procedure. SAS Inst Inc Cary Newcastle

Shane SM 2005: Health and performance of poultry in tropical climates. In: ASA handbook on poultry diseases. $2^{\text {nd }}$ Ed published by American Soybean Association, Singapore, pp. 13-20

Siegel HS 1980: Physiological stress in birds. Bio Science 30: 529-533

Thaxton P, Sadler CR, Glick B 1968: Immune response of chickens following heat exposure or injections with ACTH. Poult Sci 47: 264-266

UECAN 2002: Technical instructions for commercial layers and parent breeders. La Habana, Cuba (In Spanish) 
